\title{
Mesonephroid tumours of the ovary
}

\author{
M. C. ANDERSON AND F. A. LANGLEY \\ From the Departments of Pathology, St Mary's Hospitals, Manchester, and the Departments of \\ Obstetrics and Gynaecology, University of Manchester
}

SYNOPSIS Thirty cases of mesonephroid tumour of the ovary were studied. The differentia己 diagnosis is discussed and it is concluded that mesonephroid tumours form a distinct entity $\rightarrow$ An attempt is made to correlate the histological appearance of the tumours with the clinicaF. course and criteria are suggested which might be a guide to prognosis. Views on histogenesise are discussed but at present there seems insufficient evidence to justify any particular hypothesis. $\bigcirc$

The concept of the mesonephroid carcinoma of the female genital tract was first suggested by Schiller (1939), who described a series of nine ovarian tumours and one of the broad ligament. Their possible origins from the mesonephric apparatus were explained and he termed them 'mesonephromas'. Since then, several accounts of these tumours have appeared together with hypotheses about their histogenesis (Jones and Seegar, 1940; Teilum, 1954; Novak, Woodruff and Novak, 1954; Novak and Woodruff, 1959; Parker, Dockerty, and Randall, 1960; Suprun and Soferman, 1960; Welch and Hellwig, 1960; Wade-Evans and Langley, 1961; Lee, Dockerty, Wilson, and Symmonds, 1962; Horowitz, 1964; Villa Santa, 1964; Fawcett, Dockerty, and Hunt, 1966; Scully and Barlow, 1967; Ross and Shelley, 1968; Saavedra and Sandow, 1968). These reports show that both the histological criteria and the hypotheses about their histogenesis have changed. Although there now seems some agreement on the microscopical appearances of the tumours, there still is confusion and controversy over their mode of development, with the result that this generally recognized and distinct entity has as yet no satisfactory name. To avoid further confusion, we use the term 'mesonephroid tumours', without necessarily accepting that the name signifies their origin.

On the grounds of their general histological features, it has been suggested (Willis, 1960; Scully, 1968) that mesonephroid tumours of the Received for publication 8 July 1969. ovary may fall into the category of epithelia tumours together with the serous and mucinouso cysts and the endometrioid tumours. The mos ${ }^{-}$ generally accepted feature of distinction between $\overrightarrow{\vec{B}}$ benign and malignant epithelial ovarian tumours ${ }^{3}$ is the presence of stromal invasion (Willis, 1960 Hertig and Gore, 1966; Novak and Woodruff: 1967) but loss of differentiation (Taylor ando Greeley, 1942; Novak et al 1967) and an increase in both number and size of nucleoli in the nucles. of malignant cells (Taylor and Long, 1955) are also regarded as significant. Recently it has been suggested that an intermediate group probablyo exists which is not benign but is of low malignane potential. Whereas the borderline tumour doeso not show stromal invasion, it may show nuclear abnormalities, mitotic figures (some of whichos may be abnormal), epithelial budding, and multi- $N$ layering of the epithelium (Hertig and Gore, 1966 Nي Novak et al, 1967; Santesson and Kottmeier $\sigma$ 1968). The appearance of at least two of these features moves the tumour from the benign to the borderline group. The object of the present studyes was to assess the relationship between the malignancy of these tumours and their morphology.

The most characteristic diagnostic feature of these tumours is the presence of tubular and cystic structures in a fibrous stroma (Fig. 1). The cystse and tubules may be lined by 'hobnail' epithelium? in which the almost bare nucleus projects inte the lumen and the cytoplasm is scanty (Fig. 2) There is almost invariably a variety of patterns 


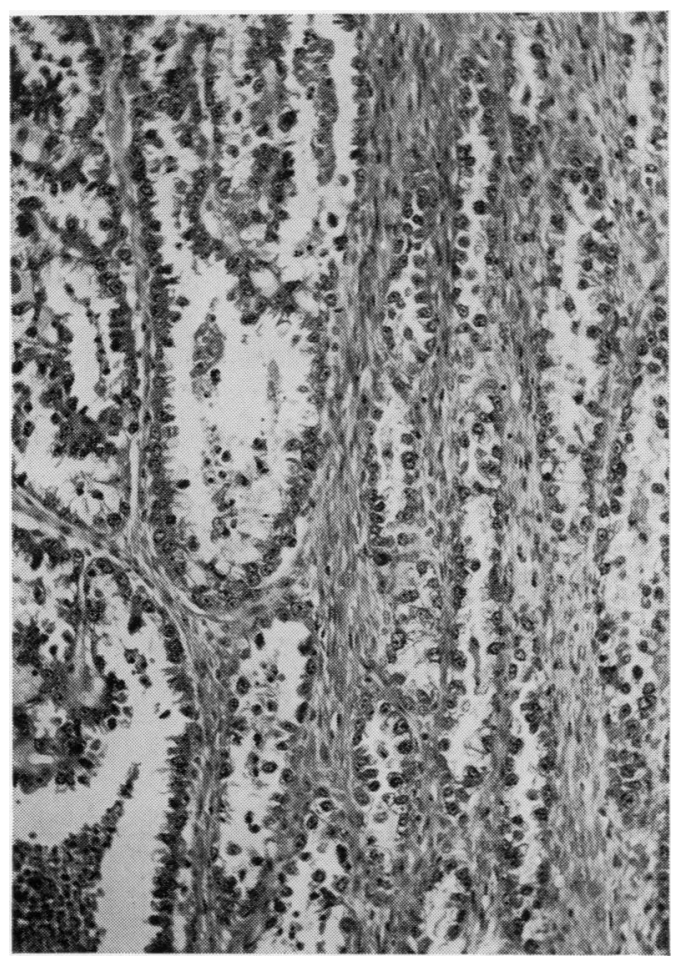

Fig. 1 Case 12: tubular and cystic structures in a fibrous stroma (haematoxylin and eosin $\times 125$ ).

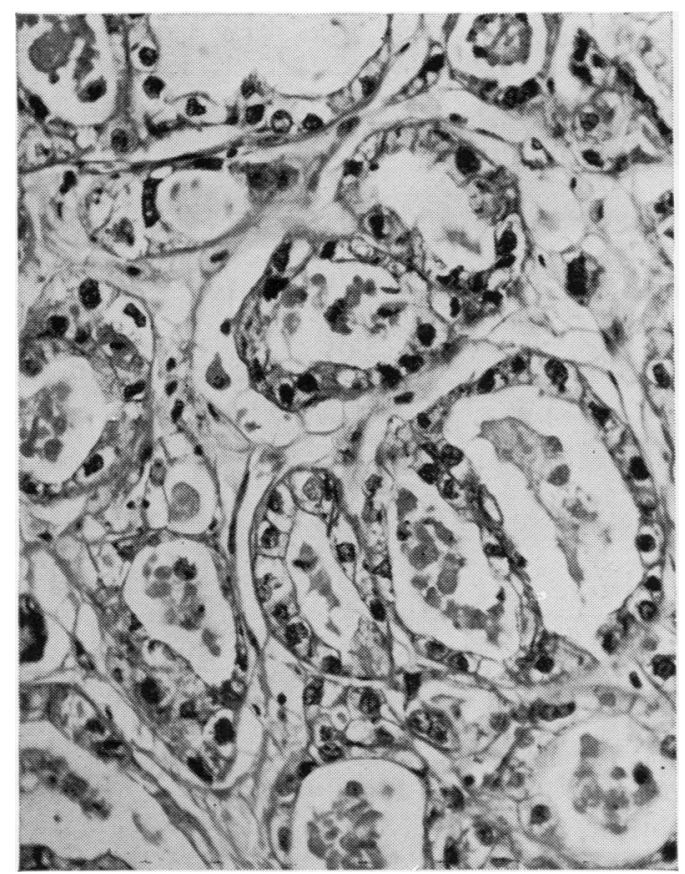

Fig. 3 Case 22: clear cells lining cystic spaces (haematoxylin and eosin $\times 250$ ).

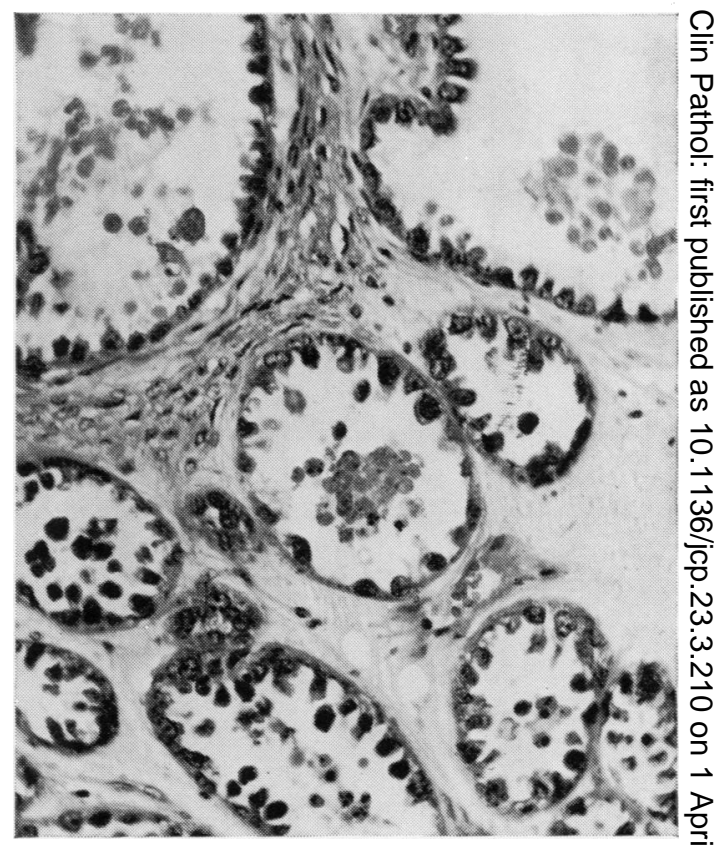

Fig. 2. Case 12: hobnail pattern of the epithelium (haematoxylin and eosin $\times 230$ ). 


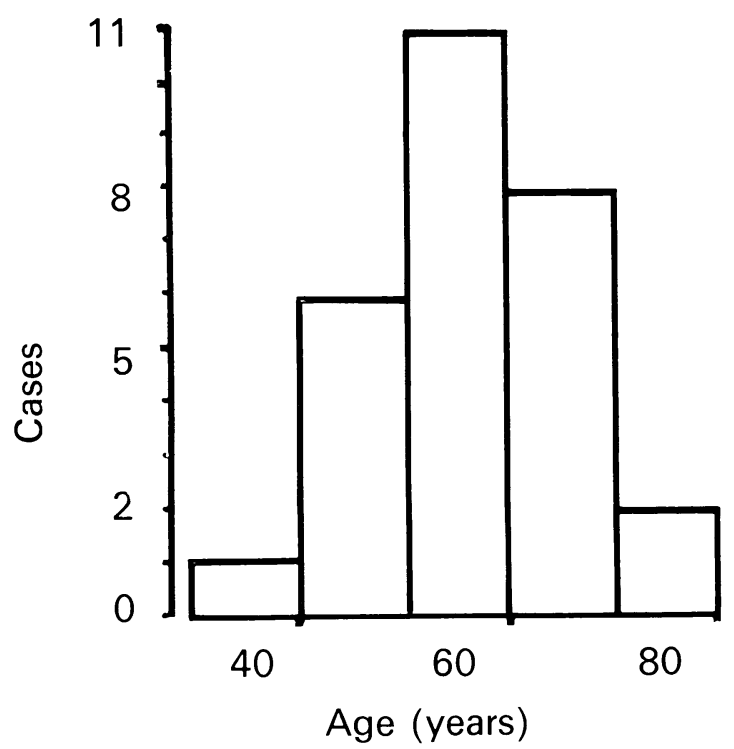

Fig. 5 Age distribution of 30 women with mesonephroid tumours.

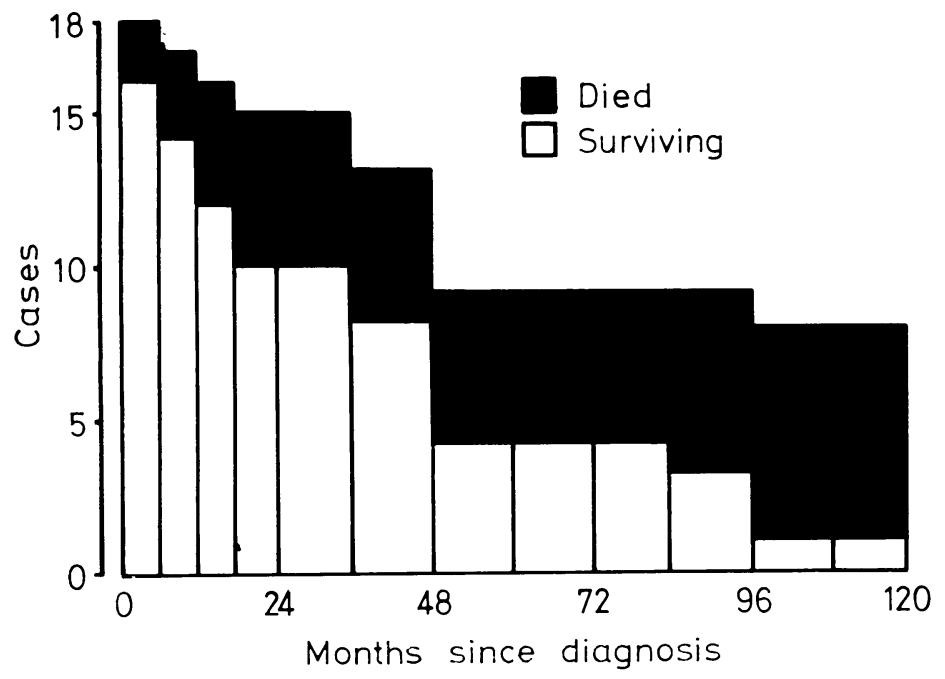

Fig. 6 Number of patients surviving and those who have died at six-monthly and I2-monthly intervals since diagnosis.

and appearances throughout the tumour. Some areas contain small cysts, some tubules, and others solid sheets of cells. Clear cytoplasm is a frequent, although not invariable, finding, and both the cells lining the cysts and tubules and those composing the solid sheets may be clear (Fig. 3). The presence of clear cells alone is not enough to justify a diagnosis of mesonephroid tumour (Scully and Barlow, 1967); several neoplasms throughout the body are composed of clear cells. Only those tumours in which there are tubules and cysts as well as clear cells are

\begin{tabular}{|c|c|c|c|}
\hline $\begin{array}{l}\text { Case } \\
\text { No. }\end{array}$ & Survival & Necropsy & Cause of Death \\
\hline 1 & $16 \mathrm{mth}$ & No & Carcinomatosis (mesonephroid@ \\
\hline 2 & $19 \mathrm{mth}$ & Yes & Carcinomatosis (mesonephroid \\
\hline 3 & $6 \mathrm{mth}$ & No & Carcinomatosis (mesonephroid $\bar{\Phi}$ \\
\hline 4 & $5 \mathrm{mth}$ & No & Carcinomatosis (mesonephroid): \\
\hline 7 & $8 \mathrm{yr}$ & No & Carcinomatosis (mesonephroid \\
\hline 8 & $9 \mathrm{yr}$ & Yes & Carcinomatosis (mesonephroich \\
\hline 9 & $3 \mathrm{yr}$ & No & Probably endometrial carcinomळ \\
\hline 16 & $8 \mathrm{mth}$ & No & Probably mammary carcinomi $\overline{0}$ \\
\hline 17 & $6 \mathrm{mth}$ & Yes & Cerebral haemorrhage \\
\hline 19 & $2 \mathrm{mth}$ & No & Not known \\
\hline
\end{tabular}

Table I Details of the 10 patients who died

classified as mesonephroid. Solid and papillar $\overrightarrow{\vec{\omega}}$ areas (Fig. 4) are frequently found but the presence is not essential for the diagnosis. To the naked eye, the tumours may be solid or cystice but most appear to be predominantly cystic wit solid areas.

\section{Material and Methods}

Sections from 39 cases which had previously beep $\overrightarrow{9}$ diagnosed histologically as mesonephroid tuo mours were re-examined. Twenty-nine of these were seen in the routine work of the hospital and the other 10 were referred for opinion fron hospitals in the area. Seven were rejected as noo satisfying the criteria for diagnosis. A tumour of the uterus and one of the cervix were alse excluded. Although these undoubtedly satisfie the criteria for diagnosis, it was though best not to include them, in view of the possible difference in histogenesis of ovarian and non-ovaria mesonephroid tumours (Wade-Evans an Langley, 1961). The remainder were 30 ovaria mesonephroid tumours from patients ranging if. age from 31 to 79 years, with the distributio shown in Figure 5. Full clinical informatio could not be obtained from a further eight case leaving 22, seen between 1954 and the end of 1967 , for detailed study. From the operation note the anatomical stage of the tumour was assessed including such points as the presence of adhesions. direct spread, metastatic deposits, completenes of removal, and whether the cystic tumouros were removed intact or with rupture.

Several slides from each case were examined and attempts made to identify and to asse quantitatively the following features: strom and blood vessel invasion; nuclear abnormalitieso mitotic figures; multilayering of the epithelium epithelial budding; the proportion of epitheli $\$$ cells to the whole. In addition, any differences i pattern were recorded. Mitotic activity was assessed by counting the number of mitotif figures seen in 100 random high-power (. 48 8 fields of each tumour. The percentage volume epithelial cells compared with the whole was measured using a Chalkley graticule with 


\begin{tabular}{|c|c|c|c|c|c|c|c|c|}
\hline $\begin{array}{l}\text { Case } \\
\text { No. }\end{array}$ & $\begin{array}{l}\text { Age } \\
(y r)\end{array}$ & Group & $\begin{array}{l}\text { Result and } \\
\text { Survival }\end{array}$ & Operative Details & $\begin{array}{l}\text { Gross } \\
\text { Appearance }\end{array}$ & $\begin{array}{l}\text { Postoperative } \\
\text { Treatment }\end{array}$ & $\begin{array}{l}\text { Percentage } \\
\text { Epithelium }\end{array}$ & $\begin{array}{l}\text { Papillary } \\
\text { Areas }\end{array}$ \\
\hline 1 & 57 & $\mathbf{A}$ & $\begin{array}{l}\text { Died } \\
8 \text { months }\end{array}$ & $\begin{array}{l}\text { Dense adhesions, secondaries in liver } \\
\text { and lymph nodes }\end{array}$ & Cystic & None & 41 & Present \\
\hline 2 & 50 & $\mathbf{A}$ & $\begin{array}{l}\text { Died } \\
19 \text { months }\end{array}$ & $\begin{array}{l}\text { Dense adhesions in lower abdomen; } \\
\text { incomplete removal }\end{array}$ & Cystic & Radiotherapy & 27 & Present \\
\hline 3 & 52 & $\mathbf{A}$ & $\begin{array}{l}\text { Died } \\
6 \text { months }\end{array}$ & $\begin{array}{l}\text { Adherent to colon; probably completely } \\
\text { removed }\end{array}$ & Cystic & None & 21 & Present \\
\hline 4 & 64 & $\mathbf{A}$ & $\begin{array}{l}\text { Died } \\
5 \text { months }\end{array}$ & $\begin{array}{l}\text { Adherent to pelvic wall; incompletely } \\
\text { removed }\end{array}$ & Solid & Antimetabolites & 35 & Present \\
\hline 5 & 50 & $\mathbf{C}$ & $\begin{array}{l}\text { Alive } \\
14 \text { years }\end{array}$ & No operative details available & Solid & None & 6 & Absent \\
\hline 6 & 62 & C & $\begin{array}{l}\text { Alive } \\
8 \text { years }\end{array}$ & Adhesions; completely removed & Solid & None & 13 & Absent \\
\hline 7 & 60 & $\mathbf{C}$ & $\begin{array}{l}\text { Died } \\
8 \text { years }\end{array}$ & $\begin{array}{l}\text { Adherent to rectum; incompletely } \\
\text { removed with rupture }\end{array}$ & Cystic & Radiotherapy & 33 & Present \\
\hline 8 & 69 & C & $\begin{array}{l}\text { Died } \\
9 \text { years }\end{array}$ & $\begin{array}{l}\text { Adherent to bowel, omentum, and } \\
\text { abdominal wall; probably not com- } \\
\text { pletely removed }\end{array}$ & Cystic & $\begin{array}{l}\text { Antimetabolites } \\
\text { and radiotherapy }\end{array}$ & 14 & Absent \\
\hline 9 & 59 & B & $\begin{array}{l}\text { Died } \\
3 \text { years }\end{array}$ & Adherent to uterus; completely removed & Solid & None & 一 & Absent \\
\hline 10 & 31 & B & $\begin{array}{l}\text { Alive } \\
14 \text { months }\end{array}$ & $\begin{array}{l}\text { Adherent to omentum; completely } \\
\text { removed with rupture }\end{array}$ & Cystic & None & 55 & Present \\
\hline 11 & 51 & B & $\begin{array}{l}\text { Alive } \\
3 \text { years }\end{array}$ & No details available & Cystic & Not known & 27 & Present \\
\hline 12 & 44 & $\mathbf{B}$ & $\begin{array}{l}\text { Alive } \\
4 \text { years }\end{array}$ & Completely removed & Cystic & Not known & 13 & Present \\
\hline 13 & 52 & B & $\begin{array}{l}\text { Alive } \\
4 \text { years }\end{array}$ & $\begin{array}{l}\text { Adherent to pelvic colon; complete } \\
\text { removal }\end{array}$ & Cystic & None & 33 & Present \\
\hline 14 & 62 & $\mathbf{B}$ & $\begin{array}{l}\text { Alive } \\
4 \text { years }\end{array}$ & $\begin{array}{l}\text { No adhesions; complete removal with } \\
\text { rupture }\end{array}$ & Cystic & Antimetabolites & 33 & Present \\
\hline 15 & 57 & B & $\begin{array}{l}\text { Alive } \\
4 \text { years }\end{array}$ & No adhesions; completely removed & Solid & Not known & 24 & Absent \\
\hline 16 & 57 & B & 8 months & $\begin{array}{l}\text { Bilateral tumour, no adhesions; } \\
\text { probably completely removed }\end{array}$ & Cystic & None & 32 & Present \\
\hline 17 & 42 & $\mathbf{B}$ & $\begin{array}{l}\text { Died } \\
6 \text { months }\end{array}$ & $\begin{array}{l}\text { Adherent to pelvic wall; incompletely } \\
\text { removed }\end{array}$ & Solid & None & 30 & Present \\
\hline 18 & 65 & B & $\begin{array}{l}\text { Alive } \\
3 \text { years }\end{array}$ & $\begin{array}{l}\text { Adherent to colon and peritoneum; } \\
\text { incompletely removed }\end{array}$ & Solid & Radiotherapy & 34 & Absent \\
\hline 19 & 61 & $\mathbf{B}$ & $\begin{array}{l}\text { Died } \\
2 \text { months }\end{array}$ & No details available & Cystic & Not known & 22 & Present \\
\hline 20 & 59 & B & $\begin{array}{l}\text { Alive } \\
18 \text { months }\end{array}$ & Adherent to loop of bowel & Solid & Not known & 17 & Absent \\
\hline 21 & 60 & $\mathbf{B}$ & $\begin{array}{l}\text { Alive } \\
5 \text { months }\end{array}$ & $\begin{array}{l}\text { Adherent to rectum, colon, and } \\
\text { bladder; incompletely removed with } \\
\text { rupture }\end{array}$ & Cystic & Antimetabolites & 18 & Present \\
\hline 22 & 60 & B & $\begin{array}{l}\text { Alive } \\
6 \text { months }\end{array}$ & $\begin{array}{l}\text { Adherent to pelvic colon; completely } \\
\text { removed with rupture }\end{array}$ & Cystic & Antimetabolites & 35 & Present \\
\hline
\end{tabular}

Table II Analysis of 22 cases of mesonephroid tumour of the ovary

randomly scattered spots. Weibel and Elias (1967) and Hennig (1967) have shown that the proportion of spots falling on epithelial tissues in any microscopic field is a measure of the volume of epithelium relative to the other tissues seen in the field. Sections were also stained for glycogen using Best's carmine, with and without salivary digestion, and for mucin using Southgate's mucicarmine. Sections of mucinous and serous tumours and endometrioid carcinomas were also stained by these methods.

\section{Results}

Figure 6 shows the number of patients living and those who have died at the end of each year since diagnosis. Those patients probably or certainly dying from causes other than ovarian carcinoma are not included. These results are consistent with those of Santesson and Kottmeier (1968), although their series showed a more rapid decrease in numbers over the first three years. Ten of the 22 patients have died and the causes of death are given in Table I. Although most did not have necropsies, it is probably safe to assume that those who had multiple secondaries, malignant ascites, and other stigmata of advanced carcinoma when last seen died from ovarian carcinoma. Cases 9 and 16 each had another malignant tumour and this probably contributed to the death of each woman.

The cases are divided into three groups as follows: group A, those who died within two years from ovarian carcinoma; group B, those who died from other causes or are still alive but have been followed up for less than five years; group. $C$, those who survived for five years or more.

Four cases fall into group A, four into group C, and the remaining 14 into group $B$. The eight cases from groups $A$ and $C$ have been examined in more detail and compared, as being clinically the most and the least malignant.

Table II shows the age, survival, operative findings, gross appearance of tumour, and the 


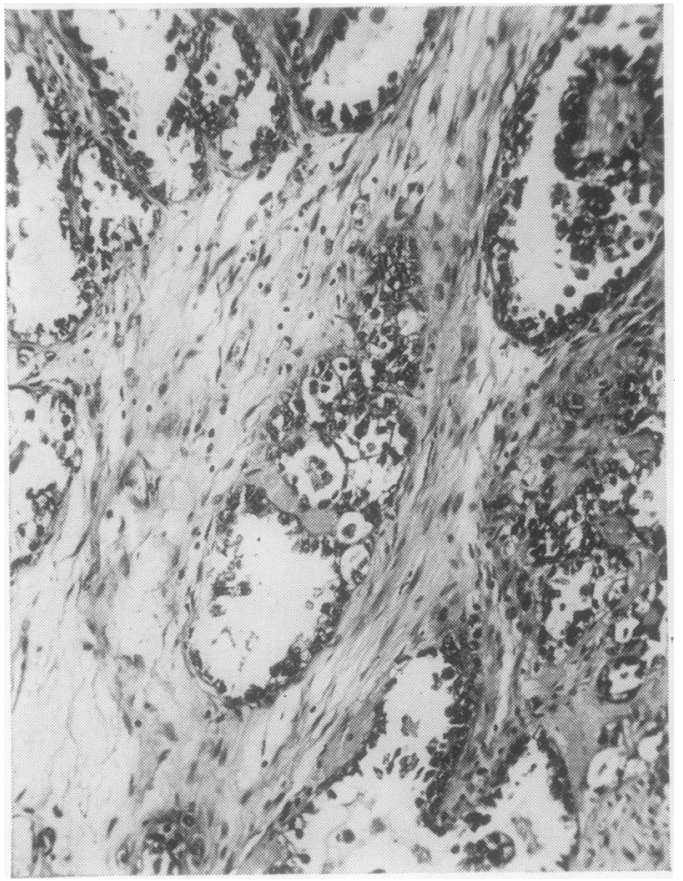

Fig. 7 Case 2: a pattern which may be due to an oblique cut but is difficult to distinguish from stromal invasion (haematexylin and eosin $\times 125$ ).

type of subsequent treatment. All four tumours in group A cases had adhesions to surrounding organs and three of them were incompletely removed. However, the tumours of three cases of group $\mathrm{C}$ also had adhesions and two of these were not completely removed. Only case 1 had secondary deposits in the liver and the lymph nodes, but apart from this case, there seems little difference in the operative findings between groups $\mathrm{A}$ and $\mathrm{C}$.

Also listed in Table II is the volume of epithelium as a percentage of the whole tumour, including stroma and the lumina of the small cysts and tubules. The results vary widely from $6 \%$ in case 5 to $55 \%$ in case 10 . The mean of cases 5,6 , 7 , and 8 , which constitute group $C$, is significantly lower than the mean of all cases, but the mean of cases $1,2,3$, and 4 , which constitute group $A$, is little higher than the mean of all cases although there is also some overlap between the groups. This suggests that the more benign tumours contain a lower proportion of epithelial cells than the more malignant ones.

It was found almost impossible to assess whether stromal invasion was occurring, - the reason for this being twofold. First, as described above, the epithelium of the tumours is arranged in cysts and tubules. Many of these are cut obliquely and through only part of the wall. Thus, a curving tubule cut in a certain plane

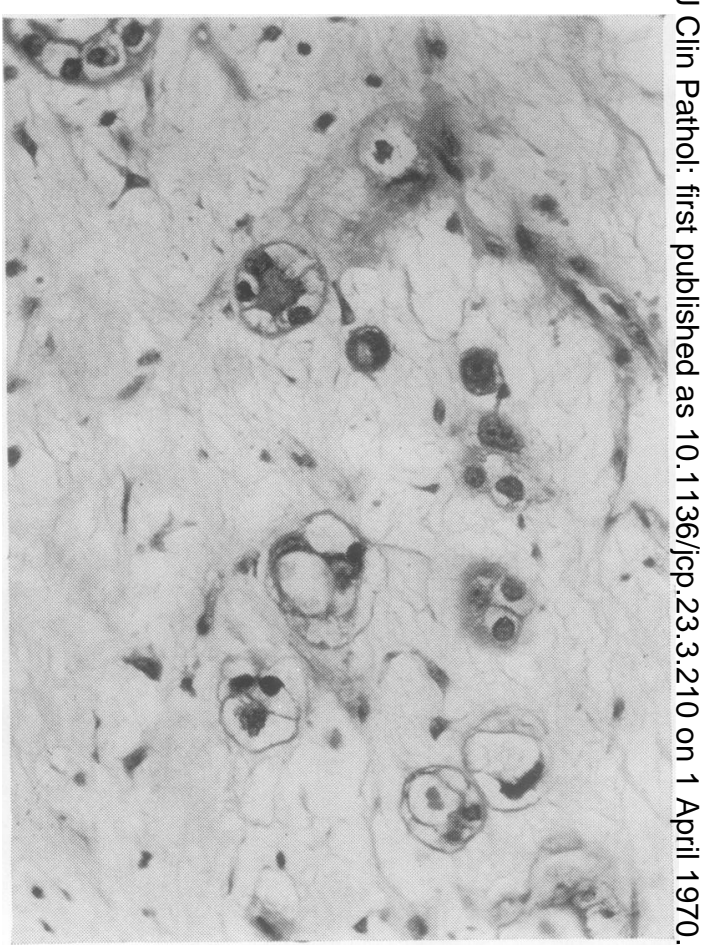

Fig. 8 Eosinophilic cells in oedematous stroma. Some cells are grouped to form small acini (haematoxylin and eosin $\times 255$ ).

might give the impression of a duct with ao proliferation of cells into the stroma at one side of it (Fig. 7). Secondly, many of the tumours presented areas in which the stroma was. oedematous and the cells widely separated Small groups of cells, resembling those of the tubules but spheroidal in shape, were scattered. around. A few of these formed small acini or narrow tubules (Fig. 8). It was impossible to sayß whether these cells scattered throughout theo stroma represented invasion. A more likely? hypothesis, suggested by Wade-Evans ando. Langley (1961), is that at these sites there is transformation of 'stromal' to 'epithelial' cells. $\Omega$

Mitotic figures were almost completely absen 0 from the sections of cases from groups $A$ and $C$ only one was found, in case 4 . Two cases from: group $B$ contained three mitotic figures. The nuclear abnormalities seen were pleomorphism variation in size, and variation in density of staining. These features were present in nearly every case, but varied from one part of the tumous to another. Case 5 was the exception in that ald the nuclei were similar. The sections from cas 17 contained several multinucleate giant cello which were present in necrotic areas but were not apparent in the non-necrotic parts of the tumouro

Multilayering of the epithelium and epithelia budding both presented similar difficulties tळ. stromal invasion since it was often impossible t ${ }^{\circ}$ 


\begin{tabular}{|c|c|c|c|c|c|c|}
\hline \multirow[t]{2}{*}{ Tumour } & & \multicolumn{2}{|l|}{ Mucin } & \multicolumn{3}{|c|}{ Glycogen } \\
\hline & & Lumen & Cells & Lumen & Cells & \\
\hline \multicolumn{7}{|l|}{ Serous } \\
\hline & Benign & 0 & Trace & 0 & $+(D)^{1}$ & \\
\hline & Benign & 0 & ++ & 0 & + (D) & \\
\hline & Malignant & $0^{+}$ & Trace & 0 & $\begin{array}{l}0 \\
0\end{array}$ & \\
\hline \multirow{2}{*}{\multicolumn{7}{|c|}{ Mucinous }} \\
\hline & Benign & + & ++ & 0 & + (D) & \\
\hline & Benign & 0 & $+t$ & + & + & \\
\hline & Malignant & Trace & ++ & 0 & 0 & \\
\hline & Malignant & + & ++ & + & + & \\
\hline \multicolumn{7}{|c|}{ Endometrioid } \\
\hline & Carcinoma & + & Trace & 0 & + & \\
\hline & Carcinoma & ++ & Trace & 0 & $+t$ & $(P)^{1}$ \\
\hline \multicolumn{7}{|c|}{ Mesonephroid } \\
\hline & Case 1 & + & 0 & 0 & + & (P) \\
\hline & Case 2 & + & 0 & 0 & + & (P) \\
\hline & Case 3 & + & 0 & Trace & + & (P) \\
\hline & Case 4 & + & 0 & + & Trace & \\
\hline & Case 6 & + & 0 & 0 & ++ & (P) \\
\hline & Case 7 & + & 0 & 0 & + & (P) \\
\hline & Case 8 & + & 0 & 0 & + & (P) \\
\hline & Case 9 & Trace & 0 & 0 & +++ & (P) \\
\hline & Case 10 & ++ & 0 & 0 & + & (P) \\
\hline & Case 11 & $+t$ & 0 & 0 & ++ & (P) \\
\hline & Case 13 & + & 0 & 0 & + & (P) \\
\hline & Case 14 & $+t$ & 0 & + & ++ & (P) \\
\hline & Case 15 & + & 0 & - & - & \\
\hline & Case 16 & + & 0 & 0 & + & (P) \\
\hline & Case 17 & - & - & 0 & ++ & (P) \\
\hline & Case 18 & Trace & 0 & 0 & + & (P) \\
\hline & Case 21 & + & 0 & 0 & + & (P) \\
\hline & Case 22 & Trace & 0 & 0 & + & (P) \\
\hline
\end{tabular}

Table III Distribution of mucin and glycogen in serous, mucinous, endometrioid, and mesonephroid tumours

${ }^{1} \mathbf{D}=$ diffuse distribution. $\mathbf{P}=$ particulate distribution.

distinguish between genuine multilayering and some forms of oblique cutting. It is likely that solid areas represent an extreme form of multilayering and budding. All the tumours except those in cases 5 and 8 had solid areas and in addition all except that in case 5 showed changes interpreted as budding and multilayering. The presence of papillary areas was an inconstant finding, 15 of the 22 cases showing some papillary areas. However, whilst all the tumours in cases in group A contained papillary areas, they were present in only one case in group C (Table II).

Table III shows the distribution of mucin and glycogen in those tumours in which material was available for additional stains and also in two cases each of serous cystadenoma, serous cystadenocarcinoma, mucinous cystadenoma, mucinous cystadenocarcinoma, and endometrioid carcinoma. The mesonephroid tumours contained mucin in the lumina of the tubules, but not in the cells, whereas glycogen was found in the cells rather than in the lumina. Glycogen was also present in the cells of the serous, mucinous, and endometrioid tumours and was seen as a diffuse coloration in the first two but in the mesonephroid tumours and one of the endometrioid tumours it was distributed within the cytoplasm as distinct particles. The endometrioid tumours further resembled the mesonephroid tumours by the presence of mucin predominantly in the lumina with very little in the cells.

\section{Discussion}

DIFFERENTIAL DIAGNOSIS

Mesenophroid tumours are to be distinguished from the endodermal sinus tumour, endometrioid carcinoma, papillary serous cystadenocarcinoma, and the adenomatoid tumour.

\section{ENDODERMAL SINUS TUMOUR (EXTRA- EMBRYONIC MESOBLASTOMA, MESO- BLASTOMA VITELLINUM)}

Teilum suggested (1950) that several of the tumours described by Schiller (1939) were germ cell tumours, characterized by a unilateral extraembryonic development similar to that of the yolk sac structures (endodermal sinuses) of a rat placenta. Support for the germ cell origin of these tumours is given by their occurrence in the sacro-coccygeal region (Huntington, Morgenstern, Sargent, Giem, Richards, and Hanford, 1963; Rao, Veliath, and Srinavasan, 1946; Brown and Langley, 1968), the anterior mediastinum (Teilmann, Kassis, and Pietra, 1967), and the region of the pineal gland (Bestle, 1968), all sites where germ cell tumours are seen. The typical features of these tumours are seen in the more highly differentiated areas, where there are groups of perivascular formations consisting of a mesodermal core with a capillary in its centre and covered by a visceral layer of cuboidal cells of epithelial appearance. The surrounding capsular sinusoid is lined by a single layer of flat cells. The stroma consists of a loose vacuolated network of stellate cells and in places there are groups of undifferentiated neoplastic embryonal cells. Cystic structures are usually present, lined either by hobnail cells or columnar epitheliumlike cells. Schiller's illustrations of mesonephric glomerulus-like structures are identical to these perivascular formations. Teilum's interpretation of these tumours is not universally accepted and the presence of glomerulus-like structures is sometimes quoted as necessary for a diagnosis of mesonephroid tumour (Welch and Hellwig, 1960; Lee et al, 1962; Mallory, Dockerty, Welch, and Hunt, 1965).

Mesonephroid tumours are seen mainly in later life; the youngest patient in the present series was 31. Endodermal sinus tumours, on the other hand, are predominantly tumours of children and young adults and are rarely seen over the age of 30 (Santesson and Marrubini, 1957).

ENDOMETRIOID CARCINOMA

Endometrioid carcinoma of the ovary is mor- 
phologically identical to endometrial carcinoma of the corpus uteri and probably arises from foci of endometriosis, although this is not proven (Gricouroff, 1968). However, clear cell areas may occur in both endometrial and endometrioid carcinomata of the ovary. If the clear-cell areas predominate a diagnosis of mesonephroid tumour may be made erroneously. Clear cells and tubules may be present in an endometrioid carcinoma but not the circular cystic spaces lined by hobnail cells nor the variation in pattern that occurs from one part of the tumour to another.

PAPILLARY SEROUS CYSTADENOCARCINOMA It is in distinguishing some mesonephroid tumours from papillary serous cystadenocarcinomata that the greatest difficulty has been encountered. Macroscopically they may be similar, consisting of fairly large cysts with solid, papilliferous projections into the cavity and containing clear, serous fluid. Microscopically, papillary formations may be seen in both. Many serous carcinomata show peg-like epithelium which may easily be confused with the hobnailing of the mesonephroid tumour. Serous carcinomata may show variations of pattern from one area to another but tubules, small cysts, and clear cells are rarely encountered.

\section{ADENOMATOID TUMOURS}

In the female these rare tumours occur usually in or near the Fallopian tubes and uterine cornua but they have been reported in the ovary (Lee, Dockerty, Thompson, and Waugh, 1950; Teel, 1958). Teilum (1954) considered that they are of mesonephric origin. Most adenomatoid tumours a e small (seldom more than $3 \mathrm{~cm}$ in diameter) and solid, with a yellowish cut surface. They consist of irregular, gland-like spaces lined by cells which have been called mesothelial, endothelial, and epithelial. These cells are set in loose or dense fibrous tissue in which smooth muscle is frequently observed. A plexiform pattern may occur in which spaces are absent or few and cells identical to those lining the places in other adenomatoid tumours may be seen. Vacuolation of the epithelium-like cells is usual, and it is apparently a confluence of adjacent vacuoles that produces the tubular or canalicular structures usually present (Jackson, 1958). The epithelium can present a hobnail appearance and, where the stroma is fibrous and no smooth muscle is seen, microscopical distinction from a mesonephroid tumour may be difficult.

\section{ASSESSMENT OF MALIGNANCY}

We found that stromal invasion, multilayering, epithelial budding, variation in nuclear size and shape, and the presence of mitotic figures did not help in assessing the prognosis of meso- nephroid tumours. The lack of mitotic figures ${ }^{c}$ in these tumours is rather surprising since they $\frac{\varrho}{\bar{F}}$ seem to be growing rapidly. It may be that our criteria for identification of mitotic figures were $\stackrel{0}{\sim}$ too rigorously drawn; unless a nucleus is clearlyㅡㅡ in well preserved metaphase, anaphase, or early telophase, it may be difficult to distinguish from degenerative changes such as karyorrhexis.

Two conclusions may perhaps be drawn from흘 the analysis in Table II. First, tumours in the $\frac{\bar{\sigma}}{\frac{1}{\sigma}}$ longer surviving cases tend to have a smaller $\stackrel{\mathbb{\Phi}}{\varrho}$ proportion of epithelial cells to the total than do the more malignant ones and, secondly, in ${ }_{\rightarrow}$ three of the four cases surviving more than five? years tumours present no papillary areas where- $\vec{\omega}$ as in all those dying within two years they do. Case 7 deserves comment, as the tumour has a large epithelial cell content and papillary areas are present. This patient died from $\omega$ carcinomatosis after eight years as a result of $\dot{\omega}$ carcinoma of the ovary. However, she was $\overrightarrow{0}$ treated by radiotherapy and it is possible that 0 treatment modified the course of the disease, prolonging life considerably. If we neglect this $D$ case, we can conclude that in the more benign tumours epithelial cells constitute less than $20 \% \overrightarrow{\overrightarrow{0}}$ of the tissue and papillary areas are absent. Wade-Evans and Langley (1961) also distinguished two groups. The first, presumably better differentiated, with simple cystic or tubular structures and little evidence of disorderly growth, and a second, in which there is $\frac{\mathscr{O}}{\not}$ greater cellular proliferation producing a florid or $\varrho$ papillary pattern. However, at that time their $\overrightarrow{\overrightarrow{0}}$ material was insufficient to relate these two 3 groups to the prognosis.

Case 5 stands out as being in a different category from all the others. The tumours had the least epithelial content, no epithelial budding, and no nuclear abnormalities. The glandular $\frac{3}{3}$ spaces were fairly uniform and regular and they were separated by stroma throughout the tumour. $\frac{0}{3}$ Hobnail epithelium lined many of the spaces. It might be regarded as a mesonephroid fibroadenoma.

As mentioned above, case 7 may have been put into group $\mathrm{C}$ under false pretences, the course $N^{\circ}$ having been modified by treatment. If this is so it $N$ is tempting to suggest that case 5 and perhaps 0 case 6 represent the benign mesonephroid $\underset{\sigma}{\sigma}$ tumour and the other 20 are all malignant ${ }^{\circ}$ tumours of various degrees. Thus it would seem that it is possible to distinguish benign from malignant mesonephroid tumours histologically, $\stackrel{+}{+}$ using the criteria of epithelial cell content and the $\frac{0}{0}$ presence of papillary areas. On this basis it is $\frac{\vec{D}}{0}$

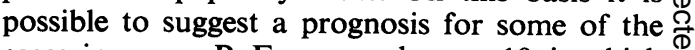
cases in group B. For example, case 10 , in which $\stackrel{\mathbb{Q}}{\varrho}$ the tumour has papillary areas and $55 \%$ of epithelial cells, may be expected to die from $\delta$ carcinoma fairly soon, whereas case 20 , with a tumour without papillary areas and $17 \%$ of epithelial cells, may survive much longer. 
We find it impossible to establish whether a histologically borderline group exists because of the difficulties associated with the identification of stromal invasion.

\section{HISTOGENESIS}

In 1954 Teilum described a group of 19 tumours from various parts of the male and female genital tracts which he regarded as mesonephric in origin. The evidence in support of this contention was in part their tubular structure, in part their occurrence in the ovary or along the tracts of the mesonephric duct or its remnants, and also the formation of homologous tumours in the epididymis, tissue derived from the mesonephric apparatus in the male. Examination of Teilum's cases, however, shows that the tumours did not constitute a homogeneous group since adenomatoid tumours and clear cell adenocarcinomas were included. Wade-Evans and Langley (1961), reviewing the literature up to 1960 , were unable to trace an account of a tumour of the epididymis similar to the eight mesonephric tumours they described in the ovary, or indeed any whose origin could be unequivocally traced to the vasa efferentia. They considered the most revealing feature of the group to be their tubular structure since this recalls both the structure of the vasa efferentia and of tumours arising in mesonephric vestiges. They concluded that mesonephric ovarian tumours arise de novo in adult tissues rather than in preexisting vestiges and that they tend to reproduce structures derived from the mesonephric tubules and not the mesonephric duct or glomeruli.

Scully and Barlow (1967) regard many of the patterns seen in these tumours as non-specific and common to many epithelial tumours. They found an important association between pelvic endometriosis and mesonephroid tumours. Their illustrations show transitions from mesonephroid tumour to endometrioid carcinoma. They conclude that these neoplasms are Müllerian in origin and related to endometrial epithelium. Four of our 22 cases had endometriosis and in one case, not included in the final series, both a mesonephroid and endometrioid tumour were present in the same ovary. Moreover, our finding of the similar distribution of glycogen and mucin in mesonephroid and endometrioid tumours may add further weight to the view that mesonephroid and endometrioid tumours are closely related.

At the present time the evidence on the histogenesis of mesonephroid tumours of the ovary is inconclusive. They do, however, form a morphologically distinct group and some of the features of the tumours recall appearances seen in the mesonephric apparatus.

We should like to thank Dr J. T. Alban Lloyd, Dr G. Sclare, Dr E. Tapp, and Dr B. L. Williams for their help in collecting material for this study, and the gynaecologists of St Mary's Hospitals, Manchester, for permission to publish their cases. We should also like to thank Professor W. I. C. Morris for the use of the facilities of his department, Mr B. W. Figg for the photomicrographs, and Dr R. Ollerenshaw, of the Department of Medical lllustration, United Manchester Hospitals, for the histograms.

\section{References}

Bestle, J. (1968). Extragonadal endodermal sinus tumours originating in the region of the pineal gland. Acta path. micriobiol. scand., 74, 214-222.

Brown, N. J., and Langley, F. A. (1968). Teratomas and rare nephrogenital tumours. In Tumours in Children, Recent Results in Cancer Research, 13, edited by H. B. Marsden and J. K. Steward. p. 259. Springer, Berlin, Heidelberg, and New York.

Fawcett, K. J., Dockerty, M. B., and Hunt A. B. Mesonephric carcinoma of the cervix uteri: a clinical and pathological study. Amer. J. Obstet. Gynec., 95, 1068-1079.

Gricouroff, G. (1968). Endometrioid tumours of the ovary. In Ovarian Cancer (UICC Monograph Series, Vol. 11), edited by F. Gentil and A. C. Junqueira, pp. 23-39. Springer, Berlin, Heidelberg and New York.

Hennig, A. (1967). In Quantitative Methods in Morphology, edited by E. R. Weibel and H. Elias, p. 103. Springer, Berlin, Heidelberg and New York.

Hertig, A. T., and Gore, H. (1966). Female genitalia. In Pathology, edited by W. A. D. Anderson, 5th edition, vol. 2, pp. 1129 1205. Mosby, St Louis. Kimpton, London.

Horowitz, S. T., Greenwald J. C., and Fenton, A. N. (1964). Mesonephroma of the ovary. Obstet. and Gynec., 24, 938-940.

Huntington, R. W., Jr., Morgenstern, N. L., Sargent, J. A., Giem, R. N., Richards, A., and Hanford, K. C. (1963). Germinal tumors exhibiting the endodermal sinus pattern of Teilum in young children. Cancer (Philad.), 16, 34-47.

Jackson, J. R. (1958). The histogenesis of the 'adenomatoid" tumor of the genital tract. Cancer (Philad.), 11, 337-350.

Jones, H. W., and Seegar, G. E. (1940). Mesonephroma of the ovary. Amer. J. Obstet. Gynec., 39, 322-329.

Lee, M. J., Jr., Dockerty, M. B., Thompson, G. J., and Waugh, J. M. (1950). Benign mesotheliomas (adenomatoid tumors) of the genital tract. Surg. Gynec. Obstet., 91, 221-231.

Lee, M. J., Dockerty, M. B., Wilson, R. B., and Symmonds, R. E. (1962). Mesonephroma of the ovary: clinical and pathologic study. Amer. J. Obstet. Gynec., 84, 677-681.

Mallory, J. J., Dockerty, M. B., Welch, J. S., and Hunt, A. B. (1965). Papillary ovarian tumors: II. Endometrial cancers and mesonephroma ovarii. Amer. J. Obstet. Gynec., 93, 880-885.

Novak, E. R., and Woodruff, J. D. (1959). Mesonephroma of the ovary. Amer. J. Obstet. Gynec., 77, 632-644.

Novak, E. R., and Woodruff, J. D. (1967). Gynecologic and Obstetric Pathology. 6th edition, Saunders, Philadelphia and London.

Novak, E. R., Woodruff, J. D., and Novak, E. R. (1954). Probable mesonephric origin of certain female genital tumors. Amer. J. Obstet. Gynec., 68, 1222-1242.

Parker, T. M., Dockerty, M. B., and Randall, L. M. (1960). Mesonephric clear cell carcinoma of the ovary: a clinical and pathological study. Amer.J. Obstet. Gynec., 80,417425.

Rao, N. R., Veliath, G. D., and Srinavasan, M. (1966). An unusual case of sacrococcygeal mesonephroma (Schiller). Cancer (Philad.), 17, 1604-1609.

Ross, L., and Shelley, E. (1968). Mesonephric carcinoma of the ovary producing hypercalcemia. Amer. J. Obstet. Gynec., $100,418-421$.

Saavedra, J. A., and Sandow, J. (1968). Hellzelliges Adenocarcinom des Ovariums (Saphir u. Lackner) und sog. Mesonephroma ovarii (Schiller) als Kombinationstumoren. Literaturstudie mit einem kasuistischen Beitrag. Arch. Gynäk., 206, 131-153.

Santesson, L., and Kottmeier, H. L. (1968). General classification of ovarian tumours. In Ovarian Cancer (UICC Monograph Series, Vol. 11), edited by F. Gentil and A. C. Junqueira, pp. 1-8. Springer, Berlin, Heidelberg, and New York.

Santesson, L., and Marrubini, G. (1957). Clinical and pathological survey of ovarian embryonal carcinomas, including socalled 'mesonephromas' (Schiller), or 'mesoblastomas' (Teilum), treated at the Radiumhemmet. Acta obstet. gynec. scand., 36, 399-419. 
Schiller, W. (1939). Mesonephroma ovarii. Amer. J. Cancer, 35, $1-21$.

Scully, R. E. (1968). Sex cord mesenchyme tumours. Pathologic classification and its relation to prognosis and treatment. In Ovarian Cancer, edited by F. Gentil and A. C. Junqueira, pp. 40-57. Springer, Berlin, Heidelberg, and New York.

Scully, R. E., and Barlow, J. F. (1967). 'Mesonephroma' of ovary: tumor of mullerian nature related to the endometroid carcinoma. Cancer (Philad.), 20, 1405-1417.

Suprun, H., and Soferman, N. (1960). A mixed 'clear-cell' adenocarcinoma with mesonephroma of the ovary. Obstet. and Gynec., 16, 175-179.

Taylor, H. C., Jr., and Greeley, A. V. (1942). Factors influencing the end-results in carcinoma of the ovary. Surg. Gynec. Obstet., 74, 928-934.

Taylor, H. C., Jr., and Long, M. E. (1955). Problems of cellular and tissue differentiation in papillary adenocarcinoma of the ovary. Amer. J. Obstet. Gynec., 70, 753-765.

Teel, P. (1958). Adenomatoid tumors of the genital tract, with special reference to the female. Amer. J. Obstet. Gynec., 75, 1347-1353.

Teilmann, I., Kassis, H., and Pietra, G. (1967). Primary germ cell tumor of the anterior mediastimum with features of endodermal sinus tumor. (Mesoblastoma vitellinum.) Acta path. microbiol. scand. , 70, 267-278.
Teilum, G. (1950). 'Mesonephroma ovarii' (Schiller): an extrá embryonic mesoblastoma of germ cell origin in the ova and the testis. Acta path. microbiol. scand., 27, 249-261.J

Teilum, G. (1954). Histogenesis and classification of mesto nephric tumors of the female and male genital system and relationship to benign so-called adenomatoid tumos (mesotheliomas). Acta path. microbiol. scand., 34, 431-4@

Villa Santa, U. (1964). Tumors of mesonephric origin in the female genital tract. Amer. J. Obstet. Gynec., 89, 680-69

Wade-Evans, T., and Langley, F. A. (1961). Mesonephric tumœ of the female genital tract. Cancer (Philad.), 14, 711-725.0

Weibel, E. R. and Elias, H. (1967). Quantitative Methods Morphology, edited by E. R. Weibel and H. Elias, p. Springer, Berlin, Heidelberg, and New York.

Welch, J. W., and Hellwig, C. A. (1960). Hypernephroid car@noma of the ovary: case report. Amer. J. Obstet. Gine? 80, 426-429.

Willis, R. A. (1960). Pathology of Tumours, 3rd. ed. Butterworths London. 